\title{
Microsatellite variation and population genetic structure of a neotropical endangered Bryconinae species Brycon insignis Steindachner, 1877: implications for its conservation and sustainable management
}

\author{
Cristianne Kayoko Matsumoto and Alexandre Wagner Silva Hilsdorf
}

\begin{abstract}
Piabanha (Brycon insignis) is a freshwater fish species from the drainages in Southeastern Brazil. During the 1950s, it was an important economic and food resource for local populations, but dramatic and continuous environmental degradation seriously jeopardized the $B$. insignis populations in the region. Microsatellite markers were used to assess the genetic structure of wild populations of $B$. insignis and compare the genetic variability and integrity of the wild populations with a captive population. Samples of DNA from 208 specimens from geographically isolated populations were analyzed. Population genetic structure was investigated using $F_{S T}, R_{S T}$ estimates as well as AMOVA. All five loci used in this study were polymorphic with observed heterozygosity ranging from $0.77( \pm 0.15)$ to $0.88( \pm 0.07)$ in the wild population and $0.90( \pm 0.09)$ in the captive population and the allelic richness average were $7.56( \pm 0.27)$ and $5.80( \pm 1.02)$, respectively. Overall genetic differences were significantly partitioned among populations $\left(F_{S T}=0.072, p=0.034\right)$. Evidence of a genetic bottleneck was found in some of the wild populations, but especially in the captive population. The results showed that genetic variability still can be found in $B$. insignis populations which are currently structured possibly due to anthropic actions. The implications of these findings for the management and conservation of $B$. insignis populations are discussed.
\end{abstract}

Piabanha (Brycon insignis) é uma espécie de peixe de água doce oriunda de drenagens da região sudeste do Brasil. Durante os anos de 1950, esta espécie foi um importante recurso econômico para populações locais. Contudo, a intensa e contínua degradação ambiental afetou seriamente as populações de $B$. insignis na região. Marcadores microssatélites foram usados para avaliar a estrutura genética de populações selvagens de $B$. insignis e comparar a variabilidade genética e integridade das populações selvagens com uma população de cativeiro. Amostras de DNA de 208 espécimes de populações geograficamente isoladas foram analisadas. A estrutura populacional foi investigada usando-se estimadores de $F_{S T}$ e $R_{S T}$ bem como AMOVA. Todos os loci usados neste estudo foram polimórficos com heterozigosidades observadas variando de $0.77( \pm 0.15)$ a 0.88 ( \pm 0.77) em populações selvagens e 0.90 ( \pm 0.09) na população de cativeiro e a riqueza alélica média foi de $7.56( \pm 0.27)$ e 5.80 ( \pm 1.02), respectivamente. A maioria das diferenças genéticas foi significativa entre populações $\left(F_{S T}=0.072, p=0.034\right)$. Evidências de efeito gargalo foram observadas em algumas populações selvagens e especialmente também na população de cativeiro. Os resultados do presente estudo mostraram que as populações de $B$. insignis ainda apresentam variabilidade genética e que estas populações estão atualmente estruturadas geneticamente provavelmente devido a ações antrópicas. As implicações destes achados para o manejo e conservação das populações de $B$. insiginis são discutidas.

Key words: Piabanha, Paraíba do Sul basin, Conservation, STR, Fish.

\section{Introduction}

Neotropical freshwater ecosystems support a very high fish diversity that has been estimated at over 6,000 species (Reis et al., 2003). The Brazilian ichthyofauna has been regarded as being an invaluable asset in the global context of biodiversity, as well as an important food source for several human populations through fisheries and aquaculture (LoweMcConnell, 1984). Different Brycon species are important as food fish in almost all Brazilian drainages. They are present in commercial fisheries and even in sport fishing. Some of them have been used in the aquaculture industry (Bittencourt \& Cox-Fernandes, 1990; Gomes et al., 2000).

The Bryconinae subfamily includes 74 nominal species,

Universidade de Mogi das Cruzes, Núcleo Integrado de Biotecnologia, Laboratório de Genética de Organismos Aquáticos e Aquicultura, CP 411, 08701-970 Mogi das Cruzes, SP, Brazil. wagner@umc.br 
42 of which are valid for the genus Brycon (Lima, 2003). Brycon species are a widespread group that ranges from southern Mexico to the La Plata River in Argentina (Hilsdorf et al., 2008).

Some authors concur that different anthropogenic impacts have jeopardized not only species in general, but also genetically different populations within species (Lande, 1988; Allan \& Flecker, 1993). The presence of several fish species in the Paraíba do Sul River and its tributaries has been jeopardized by industrial and agricultural occupation of the region over the last century. Pollution, river damming, sand extraction from the riverbed and floodplains, overfishing, and the introduction of alien species are regarded as the main causes of the loss in fish diversity and fisheries declines in the Paraíba do Sul River (Hilsdorf \& Petrere, 2002).

Brycon insignis Steindachner, 1877, commonly named piabanha, is present in drainages in Southeastern Brazil, mainly in tributary rivers of the Paraíba do Sul River Basin (Bizerril, 1999). Reproduction period ranges from December to February and induced spawning of piabanha is currently applied to produce fingerlings for farming and stocking (Andrade-Talmelli et al., 2002).

Brycon insignis was an important fishery resource in the Paraíba do Sul River Basin. In 1951, commercial fisheries caught 24 tons/year of B. insignis, which was sold in the São Paulo area of the Paraíba do Sul basin; this represented the main living income for several artisanal fishermen (Machado \& Abreu, 1952). The present situation of $B$. insignis populations is drastic. The wild populations in the State of São Paulo have become extinct and only one single stock has been maintained as a broodstock for restocking purposes since the beginning of the 1980's at a local hydroelectric power plant hatchery. Wild populations can scarcely be found. As a result, presently
B. insignis is listed on the Brazilian red list of threatened species as critically endangered (Hilsdorf et al., 2008).

Diverse molecular techniques have been used in studies of genetic diversity and conservation biology (O’Brien, 1994; Beaumont \& Bruford, 1999). Microsatellite markers have proven to be useful indicators of population structure in a variety of eukaryotic taxa, including fishes (Tautz \& Schlotterer, 1994; Jarne \& Lagoda, 1996; Menezes et al., 2008).

This study aimed: (i) to assess the genetic composition within and between samples of $B$. insignis, currently isolated by anthropic actions, through microsatellite polymorphism, (ii) to compare the genetic variability and integrity of the wild populations with a captive population, and (iii) to discuss how these findings can be used to provide genetic baseline for conservation programs of $B$. insignis.

\section{Material and Methods}

\section{Sample collection and DNA extraction}

Samples were collected between 2001 and 2005 after an initial survey to identify the occurrence of $B$. insignis in drainages in Southeastern Brazil. Locations of wild populations were identified by local fishermen, who indicated possible sites for $B$. insignis sampling.

Fin clips were obtained from 208 adult fish and the individuals were returned to the water without being killed. Sampling locations were as follows: Paraíba do Sul River (PSR), Imbé River (IMR), Muriaé River (MUR), Itabapoana River (ITR) and the São João River (SJR) (Fig. 1, Table 1). In addition, the $B$. insignis broodstock (PHC) kept in the power plant hatchery was sampled.

Total genomic DNA extraction was performed according

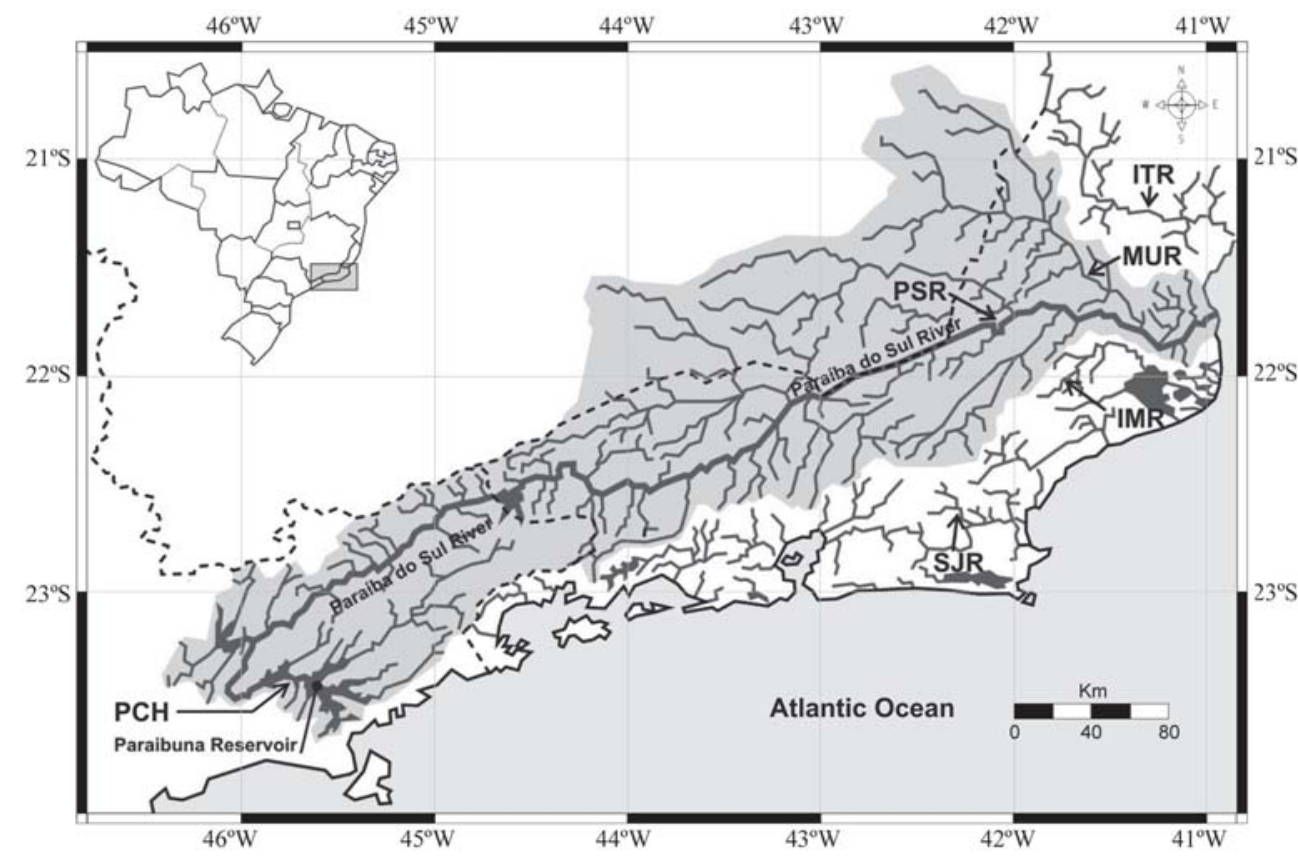

Fig. 1. Location of sampling sites of Brycon insignis in drainages in Southeastern Brazil. Power Company Hatchery (PCH), São João River (SJR), Paraíba do Sul River (PSR), Imbé River (IMR), Muriaé River (MUR) and Itabapoana River (ITR). 
Table 1. Sampling sites and respective drainages, sampling years and number of samples.

\begin{tabular}{|c|c|c|c|c|}
\hline \multicolumn{2}{|l|}{ Sampling site } & Drainage & \multicolumn{2}{|c|}{ Sampling yearSample size } \\
\hline Power Company Hatcl & $(\mathrm{PCH})$ & araíba do Sul & 2001 & 40 \\
\hline Imbé River & (IMR) & araíba do Sul & 2003 & 40 \\
\hline Muriaé River & (MUR) & araíba do Sul & 2005 & 18 \\
\hline Paraíba do Sul River & (PSR) & araíba do Sul & $2001 / 2002$ & 40 \\
\hline Itabapoana River & (ITR) & Itabapoana & 2002 & 40 \\
\hline São João River & (SJR) & São João & $2004 / 2005$ & 30 \\
\hline
\end{tabular}

to the methods of Taggart et al. (1992), except for the use of STE (0.1 M NaCl; 0.05 M Tris-HCl; 0.01 M EDTA) with a lower EDTA in the buffer concentration.

\section{Microsatellite marker amplification and genotyping}

Four microsatellite primers designed for $B$. opalinus (Barroso et al., 2003) and three B. cephalus (Barroso, 2003) were tested in $B$. insignis. After optimizing PCR conditions, five dinucleotide motif primers (Table 2) were selected for the genetic analysis because they generated reproducible amplification within the size range expected and could be scored on a polyacrylamide gel.

The PCR reactions were performed in a $10 \mu$ reaction volume containing $50 \mathrm{ng}$ of the template DNA, $2 \mu \mathrm{M}$ of each primer, $0.25 \mathrm{mM}$ each of dNTPs, $0.5 \mathrm{U}$ of Taq DNA polymerase, $1 \mu \mathrm{l}$ $10 \mathrm{X}$ reaction buffer, and $\mathrm{MgCl}_{2}$ concentrations as indicated in Table 2. For all loci, samples were subjected to an initial denaturation step at $94^{\circ} \mathrm{C}$ for $3 \mathrm{~min}$, followed by 30 cycles of $94^{\circ} \mathrm{C}$ for $1 \mathrm{~min}$, at annealing temperature for 25 seconds, $72^{\circ} \mathrm{C}$ for $1 \mathrm{~min}$, and a final extension at $72^{\circ} \mathrm{C}$ for $10 \mathrm{~min}$ (Table 2). Negative and positive controls were implemented to verify the consistency and reproducibility of the amplification products.

The PCR products were electrophoresed on $7.5 \%$ polyacrylamide gel at $6,000 \mathrm{~W}$ for 3 hours. The DNA fragments were revealed by standard silver staining techniques. Microsatellite allele sizing for every individual was estimated manually by two independent people comparing the samples to molecular weight standards (10 bp ladder; Invitrogen) using the “Alpha Index 6.5” program (AlphaImager" ${ }^{\mathrm{TM}}$ - Alpha Innotech Corporation).

\section{Analysis of genetic variability within and among populations}

Genetic variability within populations was estimated by calculating the mean number of alleles per locus $(A)$, allelic richness per locus per sample ( $A r$ ), considering the alleles per locus independent of sample size (El Mousadik \& Petit, 1996), gene diversity per locus and sample using an unbiased estimator ( $h \mathrm{~s})$ (Nei, 1987). $F_{\text {IS }}$ values per locus per sampling site were calculated using FSTAT version 2.9.3.2 (Goudet, 2002). Deviations from Hardy-Weinberg expectations (HWE) were performed by an exact test using the Markov-Chain randomization approach (Guo \& Thompson, 1992) implemented by Arlequin, version 3.1 (Excoffier et al., 2005). The software Micro-Checker (Van Oosterhout et al., 2004) was employed to infer the causes of possible departure from HWE produced for null alleles (mutation in flanking region), misscoring (stuttering), and large-allele dropout (short allele dominance).

Statistical comparisons were carried out to verify differences of Ar, hs and Ho between the sites using a oneway analysis of variance (ANOVA) followed by Student Newman Keuls test $(p>0.05)$ implemented by the software Sigma Stat for Windows version 2.0 (Jandel Corporation).

The overall population subdivision was estimated using Wright's F statistic (Weir \& Cockerham, 1984) grounded in the assumptions of the infinite allele model by the HIERFSTAT package (Goudet, 2005). $R_{S T}$ was calculated taking into account the stepwise mutation model (SMM) (Slatkin, 1995) by RST CALC (Goodman, 1997). An exact test for population differentiation was performed by testing the hypothesis of random distribution of the individuals between pairs of populations (Goudet et al., 1996). A sequential Bonferroni adjustment was implemented to verify the significance levels for all the above simultaneous comparisons (Rice, 1989). Results are presented as mean $\pm S E$.

Additionally, a $\Phi_{\mathrm{ST}}$ (Weir and Cockerham, 1984) was calculated by the analysis of molecular variance (AMOVA; Excoffier et al., 1992) with 10,000 permutations to test the significance of hierarchical population analysis using ARLEQUIN, version 3.1 (Excoffier et al., 2005).

The graphical representation based on genetic distance data (Nei, 1972) was constructed by UPGMA algorithm (Felsenstein, 1985), implemented in TFPGA “Tools for Population Genetic Analyses”, version 1.3 (Miller, 1997).

BOTTLENECK 1.2.02 (Cornuet \& Luikart, 1996) test results were used for detecting a recent reduction in the effective

Table 2. Primer sequence, microsatellite motif, conditions for amplification and accession number on Genebank used for microsatellite genotyping of Brycon insignis.

\begin{tabular}{|c|c|c|c|c|c|}
\hline Locus & Primer sequence (5’-3’) & Motif & Annealing temp. $\left({ }^{\circ} \mathrm{C}\right)$ & {$\left[\mathrm{MgCl}_{2}\right](\mathrm{mM})$} & GeneBank accesion number \\
\hline BoM1 & $\begin{array}{l}\text { F: CCATCTCTACTTTTTGGTTCC } \\
\text { R:TGCCCAGATACAGCCC }\end{array}$ & (CA) & 60 & 2.5 & AF513629 \\
\hline BoM2 & $\begin{array}{l}\text { F:CTGGGCAGCGGAAGAG } \\
\text { R: CCCACATCTCTCCCСTTCG }\end{array}$ & (CA) & 60 & 2.0 & AF513630 \\
\hline Bom13 & $\begin{array}{l}\text { F:CATTTCCTCAGTCCTTTTCAGC } \\
\text { R: CCCACTTAGGGTCGCAC }\end{array}$ & (CA) & 62 & 3.0 & AF513621 \\
\hline ВC48-6 & $\begin{array}{l}\text { F:GGAGGACAGTGAGTGGACG } \\
\text { R:GTTTGCTTGGACATCTGC }\end{array}$ & (CA) & 62 & 3.0 & AF513622 \\
\hline BC48-10 & $\begin{array}{l}\text { F:GTTCCACCTATTGCTGACAC } \\
\text { R:GAAAATACTACTCTACGGGGAC }\end{array}$ & (CA) & 65 & 2.0 & AF513628 \\
\hline
\end{tabular}


population size, to assess each population according to differences in heterozygosity excess or deficiency and to differences in allele number in a given population. Heterozygosity excess was measured under the two-phase mutation model (TPM, with 90\% SMMs, 5,000 iterations), which is the intermediate model between the IAM and the SMM and is recommended for microsatellite loci evolution calculations (Di Rienzo et al., 1994). The Wilcoxon test option was chosen to evaluate the significance level of heterozygosity excess or deficiency. This test provides relatively high statistical power and can be applied to few loci with low sample sizes.

\section{Results}

Efficiency of cross-amplification in microsatellite primers

This is the first study to examine genetic variability in $B$. insignis. No information on the genomic sequence of this species is available for the purpose of designing specific primer pairs for microsatellite loci. The use of microsatellite loci characterized from other Brycon species has proven to be suitable for microsatellite amplification of $B$. insignis. Similar conclusions were reached by Abila et al. (2004) for cichlid fish, and Salgueiro et al. (2003) for cyprinid fish. All five primer pairs used in the present study were polymorphic and amplified consistent and reproducible microsatellite alleles with the allele size ranging from 72 (BC48-10) to 194 bp (B0M13) (Table 3).

\section{Allelic diversity and Hardy-Weinberg equilibrium}

Sixty-one alleles were observed and the average number of alleles per locus per sample location ranged from 5.8 ( \pm 1.02$)$ in PHC to 9.4 ( \pm 1.40$)$ in PSR. Nei's gene diversity ( $h s$ ) was high among wild populations and also in the hatchery broodstock. It was found that this measurement of genetic variation ranged from $0.70( \pm 0.11)$ to $0.83( \pm 0.05)$ (Table 3). Allelic richness (Ar) was lower in the hatchery fish when compared to the other populations although ANOVA analysis did not show significant differences among populations for Ar, $h s$ and Ho parameters (Bonferroni adjusted alpha).

The average of the observed and expected heterozygosities per location per sample ranged from 0.77 $( \pm 0.15)$ to $0.90( \pm 0.90)$, and from $0.72( \pm 0.04)$ to $0.83( \pm 0.10)$, respectively (Table 3). Significant departures from HWE were verified by genotype specific testing in most of the genotypes in all population samples of $B$. insignis, with significant heterozygote excess for loci BoM 1, BoM 13 and BC48-6 and heterozygote deficit for loci BoM2 for all populations and BC48-10 for wild populations (Table 3). All HWE population comparisons remained significant after sequential Bonferroni correction ( $p<0.001$ ), except loci Bc48-10 for IMR, BoM2 for MUR and BoM2 for SJR that showed an excess of heterozygosity in most loci and populations (Negative $F_{I S}$ values) (Table 3). Loci BoM2 and BC48-10 showed deficit of heterozygosity across the wild population, but only in locus BoM2 the presence of null allele was detected through the MICRO-CHECKER software analysis.

\section{Genetic bottleneck}

Paraíba do Sul (PSR), Itabapoana (ITR) and Imbé (IMR) Rivers wild populations and the captive stock (PHC) showed a significant departure $(p<0.05)$ from drift-mutation equilibrium under the TPM (90-10\% SMM-IAM), determined with the Wilcoxon test. Populations from the São João River (SJR) and Muriaé (MUR) Rivers did not demonstrate significant heterozygosity excess $(p>0.05)$. Despite Itabapoana (ITR) and Imbé (IMR) populations having shown significant heterozygosity excess under the TPM model, under the strict SMM model, these populations did not demonstrate a significant probability $(p=0.11)$ of heterozygosity excess. Therefore, it is not certain that the ITR and IMR populations went through a bottleneck.

\section{Intrapopulation diversity and genetic structuring}

Pairwise $R_{S T}$ values (Table 4) showed significant differentiation between all population pairs. Lower levels of genetic structuring were detected between the IMR and PSR populations, as well as between those two and the ITR population. Moderate genetic differentiation was observed among the MUR and the PSR, IMR, and ITR populations. In average, the higher values of pairwise genetic differentiation were found when SJR and PHC were compared to all other sampling sites.

For the AMOVA analysis, considering all populations as a group, we found that $7.37 \%$ of the total genetic variance was due to differences among populations $\left(\Phi_{S T}=0.07, p<0.001\right)$ (Table 5). If hierarchical AMOVA analysis were implemented with the PHC as one group, the SJR as another, and IMR, ITR, MUR, and PSR as third group, there would still be a significant separation between groups $\left(\Phi_{C T}=0.068, p<0.05\right)$. This estimate corroborates the effect of location at the level of population differentiation estimated by the HIERFSTAT package $\left(F_{S T}=0.072, p=0.034\right)$.

\section{Discussion}

\section{Genetic diversity in wild populations}

Despite the large biodiversity of Neotropical freshwater fishes, many of them important for fishery and aquaculture, there are a few studies of population genetics using microsatellites (Oliveira et al., 2009). The findings herein revealed genetic differences between $B$. insignis populations, as was expected because the currently physical isolation among them.

The present study demonstrates that Loci BoM2 exhibited heterozygosity deficiency throughout the wild populations surveyed, which suggests that the presence of null alleles is the cause of the heterozygosity deficiency at this locus. The excess of homozygotes observed in the loci BC48-10 in the wild populations is possibly attributable to the Wahlund effect since no null allele was detected for this locus.

The presence of heterozygosity excess in the other loci suggests a possible reduction in the size of the populations of $B$. insignis in this study. Considering a significant departure 
Table 3. Summary statistic for genetic diversity at five microsatellite loci of Brycon insignis in six sampling sites: number of alleles (A), allelic richness $\left(\mathrm{A}_{\mathrm{R}}\right)$; Nei's genetic diversity (hs), observed $\left(H_{\mathrm{O}}\right)$ and expected heterozygosity $\left(H_{\mathrm{E}}\right)$; and inbreeding coefficient $\left(F_{\text {IS }}\right)$. NS - Not significant and ${ }^{* *}$ - Highly significant $(p<0.01)$ after Bonferroni adjustment (nominal $\left.\alpha=0.05\right)$. Power Company Hatchery (PCH), São João River (SJR), Paraíba do Sul River (PSR), Imbé River (IMR), Muriaé River (MUR) and Itabapoana River (ITR).

\begin{tabular}{|c|c|c|c|c|c|c|c|c|}
\hline Locality & Locus & Allele size range (bp) & $\mathrm{A}$ & $\mathrm{Ar}$ & $h s$ & $\mathrm{Ho}$ & $\mathrm{He}$ & $F_{I S}$ \\
\hline \multirow{6}{*}{ PCH } & BoM1 & 146-162 & 8 & 7.40 & 0.85 & $1.00 * *$ & 0.86 & -0.17 \\
\hline & BoM2 & 118-134 & 8 & 7.68 & 0.83 & $0.55 * *$ & 0.84 & 0.34 \\
\hline & BoM13 & $156-176$ & 6 & 5.10 & 0.68 & $1.00 * *$ & 0.68 & -0.46 \\
\hline & BC48-6 & $113-135$ & 3 & 3.00 & 0.62 & $1.00 * *$ & 0.70 & -0.43 \\
\hline & BC48-10 & $74-90$ & 4 & 3.45 & 0.62 & $0.97 * *$ & 0.63 & -0.56 \\
\hline & All loci & & $5.80(1.02)$ & $5.32(0.97)$ & $0.72(0.05)$ & $0.90(0.09)$ & $0.74(0.04)$ & \\
\hline \multirow{6}{*}{ IMR } & BoM1 & $144-164$ & 10 & 8.63 & 0.86 & $1.00 * *$ & 0.86 & -0.16 \\
\hline & BoM2 & 118-136 & 9 & 8.21 & 0.85 & $0.59 * *$ & 0.84 & 0.30 \\
\hline & BoM13 & 154-186 & 11 & 9.34 & 0.87 & $1.00 * *$ & 0.87 & -0.14 \\
\hline & ВС48-6 & $113-147$ & 4 & 3.45 & 0.66 & $0.89 * *$ & 0.66 & -0.36 \\
\hline & BC48-10 & $72-94$ & 12 & 10.20 & 0.86 & $0.77^{\mathrm{NS}}$ & 0.86 & 0.10 \\
\hline & All loci & & 9.20 (1.93) & $7.97(1.18)$ & $0.82(0.04)$ & $0.85(0.08)$ & $0.82(0.04)$ & \\
\hline \multirow{6}{*}{ MUR } & BoM1 & $146-164$ & 6 & 6.00 & 0.80 & $1.00 * *$ & 0.80 & -0.25 \\
\hline & BoM2 & $120-136$ & 6 & 6.00 & 0.64 & $0.50^{\mathrm{NS}}$ & 0.64 & 0.22 \\
\hline & BoM13 & 158-184 & 9 & 9.00 & 0.88 & $1.00 * *$ & 0.88 & -0.13 \\
\hline & ВС48-6 & 113-141 & 5 & 5.00 & 0.69 & $1.00 * *$ & 0.70 & -0.44 \\
\hline & BC48-10 & $74-94$ & 10 & 10.0 & 0.88 & $0.83 * *$ & 0.88 & 0.06 \\
\hline & All loci & & $7.20(0.97)$ & $7.20(0.97)$ & $0.78(0.05)$ & $0.86(0.09)$ & $0.78(0.05)$ & \\
\hline \multirow{6}{*}{ PSR } & BoM1 & $140-164$ & 12 & 11.09 & 0.90 & $1.00 * *$ & 0.90 & -0.10 \\
\hline & BoM2 & $118-140$ & 10 & 8.22 & 0.84 & $0.63 * *$ & 0.85 & 0.29 \\
\hline & BoM13 & 158-194 & 11 & 9.60 & 0.88 & $1.00 * *$ & 0.88 & -0.13 \\
\hline & BC48-6 & $113-147$ & 4 & 3.70 & 0.64 & $0.95 * *$ & 0.65 & -0.46 \\
\hline & BC48-10 & $72-92$ & 10 & 9.13 & 0.87 & $0.82 * *$ & 0.87 & 0.06 \\
\hline & All loci & & $9.40(1.4)$ & $8.34(1.25)$ & $0.83(0.04)$ & $0.88(0.07)$ & $0.83(0.04)$ & \\
\hline \multirow{6}{*}{ ITR } & BoM1 & $144-164$ & 11 & 10.28 & 0.89 & $1.00 * *$ & 0.89 & -0.11 \\
\hline & BoM2 & 118-138 & 11 & 9.60 & 0.86 & $0.60 * *$ & 0.86 & 0.30 \\
\hline & BoM13 & 156-184 & 8 & 7.28 & 0.78 & $1.00 * *$ & 0.78 & -0.28 \\
\hline & BC48-6 & 113-135 & 3 & 3.00 & 0.63 & $1.00 * *$ & 0.63 & -0.59 \\
\hline & BC48-10 & 74-94 & 9 & 7.33 & 0.83 & $0.75^{* *}$ & 0.83 & 0.10 \\
\hline & All loci & & $8.40(1.47)$ & $7.50(1.76)$ & $0.80(0.05)$ & $0.87(0.08)$ & $0.80(0.04)$ & \\
\hline \multirow{6}{*}{ SJR } & BoM1 & $140-164$ & 12 & 10.69 & 0.89 & $1.00 * *$ & 0.90 & -0.11 \\
\hline & BoM2 & $124-136$ & 6 & 4.82 & 0.27 & $0.23^{\mathrm{NS}}$ & 0.27 & 0.16 \\
\hline & BoM13 & $160-180$ & 8 & 7.79 & 0.85 & $1.00 * *$ & 0.86 & -0.17 \\
\hline & BC48-6 & 113-135 & 4 & 3.99 & 0.70 & $1.00 * *$ & 0.70 & -0.43 \\
\hline & BC48-10 & $72-94$ & 8 & 7.02 & 0.81 & $0.63 * *$ & 0.81 & 0.22 \\
\hline & All loci & & $7.60(1.32)$ & $6.80(1.18)$ & $0.70(0.11)$ & $0.77(0.15)$ & $0.71(0.11)$ & \\
\hline
\end{tabular}

from mutation-drift equilibrium based on the differences in standardized test outcomes under the assumption that all loci fit the TPM mutation model, a possible bottleneck was detected in the IMR, ITR and PSR populations.

In fact, $B$. insignis wild populations are jeopardized by continuous anthropogenic habitat alteration. The species have vanished from the southern region of the Paraíba do Sul basin and just a few populations remain in tributaries in the northernmost area and nearby drainages of the Paraíba do Sul basin. These few $B$. insignis wild populations are isolated due to physical and environmental obstacles such as hydroelectric dams and industrial and urban effluents. Also, the difficulty in sampling specimens for the present study together with the lack of $B$. insignis in the commercial fisheries may be an indication of overall population decline. These results reinforce the listing of $B$. insignis on the Official List of Endangered Fish Species issued by the Brazilian government.

The overall $F_{\mathrm{ST}}, R_{\mathrm{ST}}$ and $\Phi_{\mathrm{ST}}$ estimates among wild populations indicated that most of the $B$. insignis populations were significantly differentiated from each other. Pairwise genetic difference evaluations showed that SJR is the most genetically distinct population. SJR is a geographically isolated population located in a drainage basin near the Atlantic Ocean (Fig. 1). The presence of $B$. insignis species (verified by $16 S$ mitochondrial DNA sequencing, data not shown) was an interesting finding, since there are few records of $B$. insignis occurrence outside the Paraíba do Sul basin. Furthermore, the genetic differences found between SJR and the other $B$. insignis populations and its geographic isolation make SJR a unique genetic pool that should be preserved as a MU - Management Unit - (Moritz, 1994).

According to Wright (1978) $F_{S T}$ or its analogous $R_{S T}$ estimates below 0.05 indicates little genetic differentiation; an estimate between 0.05 and 0.15 , moderate differentiation; an estimate between 0.15 and 0.25 , great differentiation; and estimates above 0.25 , very great genetic differentiation. 
Table 4. Pairwise $R_{\mathrm{ST}}$ statistics (Slatkin, 1995) between Brycon insignis populations based on five microsatellite loci. All pairwise $p<0.01$. Power Company Hatchery (PCH), São João River (SJR), Paraíba do Sul River (PSR), Imbé River (IMR), Muriaé River (MUR) and Itabapoana River (ITR).

\begin{tabular}{ccccccc}
\hline Populations & PHC & IMR & MUR & PSR & ITR & SJR \\
\hline PHC & - & & & & & \\
IMR & 0.096 & - & & & & \\
MUR & 0.221 & 0.108 & - & & & \\
PSR & 0.182 & 0.038 & 0.174 & - & & \\
ITR & 0.092 & 0.027 & 0.078 & 0.097 & - & \\
SJR & 0.156 & 0.050 & 0.119 & 0.108 & 0.033 & - \\
\hline
\end{tabular}

Table 5. Analysis of Molecular Variance (AMOVA) among populations of Brycon insignis (based in 1023 permutations). Structure tested: Group 1 (PCH); Group 2 (SFR); Group 3 (IMR, ITR, MUR and PSR).

\begin{tabular}{lcccc}
\hline Source of variation & $\begin{array}{c}\text { Variance } \\
\text { components }\end{array}$ & $\begin{array}{c}\text { Percentage } \\
\text { of variation }\end{array}$ & $\Phi$-statistics & p-value \\
\hline Among groups & 0.1478 & 6.86 & $\Phi_{C T}=0.0686$ & $<0.05$ \\
\hline $\begin{array}{l}\text { Among populations } \\
\text { within groups }\end{array}$ & 0.0645 & 3.00 & $\Phi_{C S}=0.03216$ & $<0.001$ \\
\hline $\begin{array}{l}\text { Among individuals } \\
\text { within populations }\end{array}$ & -0.1930 & -8.96 & $\Phi_{I S}=-0.0994$ & $>0.05$ \\
\hline Within individuals & 2.1346 & 99.10 & $\Phi_{I T}=0.00895$ & $>0.05$ \\
\hline
\end{tabular}

However it is important to point out that even low $F_{S T}$ or $R_{S T}$ estimates $(<0.05)$ may reflect an important genetic differentiation between populations (Balloux \& LugonMoulin, 2002).

The populations located north of the Paraíba do Sul basin showed low to moderate levels of genetic structuring according to $R_{S T}$ pairwise estimates (Table 4). IMR, PSR, and ITR were genetically more similar to each other, whereas MUR showed moderate genetic differences. ITR is located in the Itabapoana river basin without contact with Paraíba do Sul basin and the other populations IMR, PSR and MUR are separated in different levels by six hydroelectric power plant dams. Despite the current physical isolation, this low to moderate genetic differences between the IMR, PSR, ITR and MUR may still reflecting the past connection between the population from this rivers.

The same genetic structuring pattern was also observed in two other Brycon species: B. hillari (Valenciennes) (Sanches \& Galetti Jr., 2007) and B. opalinus (Cuvier) (Barroso et al., 2005).

UPGMA dendrogram (Fig. 2) based on Nei's genetic distance (1978) showed a pattern of population division that corroborates the RST pairwise population analysis, where the lowest distances were verified among IMR, PSR, ITR sites.

\section{Genetic diversity in the captive broodstock ( $\mathrm{PCH})$}

The restocking program is one of the legal mitigation measures used by hydroelectric power companies in Brazil to reduce the impacts on the ichthyofauna caused by river impoundments. The $B$. insignis restocking started in the

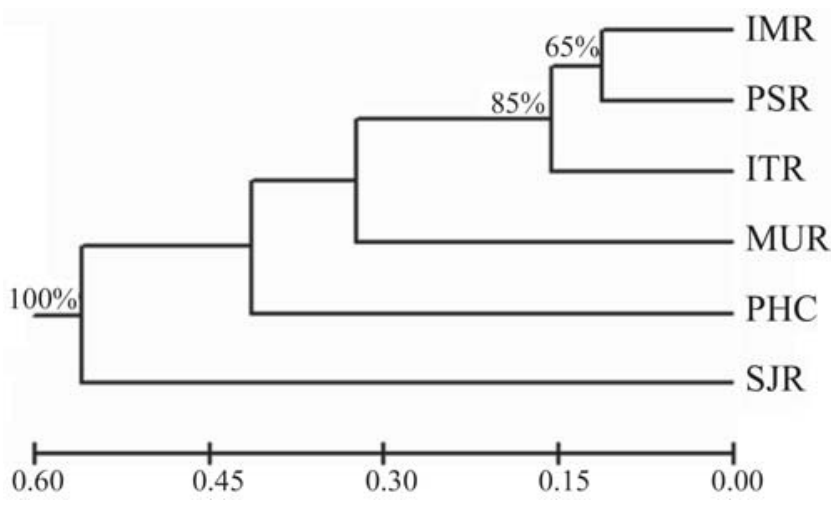

Fig. 2. UPGMA clustering of the Nei's genetic distance (1972) of the Brycon insignis sampling locations based on six microsatellite loci. Bootstrap values above $50 \%$ are shown above branches indicating percentage support in 5000 permutations. Power Company Hatchery (PCH), São João River (SJR), Paraíba do Sul River (PSR), Imbé River (IMR), Muriaé River (MUR) and Itabapoana River (ITR).

1980's. This species was selected because of its vulnerability and extremely reduced number of wild individuals in rivers located near hydroelectric reservoirs.

The results of the bottleneck analysis showed that the PHC broodstock went through some level of reduction during stock the formation. As a result, the heterozygosity values found in the hatchery broodstock sample were high and allelic richness was low (Table 3 ).

Little information about the formation of the PHC broodstock is available. A reduced effective population size during broodstock creation in breeding programs generally is the first problem found in hatcheries responsible for reintroductions. This, combined with poor breeding management, is the cause of the loss of genetic variability in captive stocks.

The $R_{S T}$ values show significant differences when PHC is compared to other populations, which may have been caused by the bottleneck effect during the broodstock formation or may even be attributable to the fact that the individuals originally caught for the PHC breeding program in the early 1980 's possibly originated from a distinct genetic population. Consequently, the broodstock kept at the hatchery has likely been maintaining the genetic diversity formerly present in some rivers, which currently no longer exist in natural populations of $B$. insignis.

\section{Implications for conservation and management of Brycon insignis}

There is no information available about the biological aspects of B. insignis migration pattern. Studies of Brycon orbignyanus (Valenciennes) showed that this species is regarded as a short-distance migrant, i.e., fish that migrate less than $100 \mathrm{~km}$ (Agostinho et al., 2003). If the migratory movement of $B$. insignis follows the same short-distance pattern, as found in $B$. orbignyanus, discrete populations 
should be more genetically different from each other.

The depletion of $B$. insignis populations has been a continuous process attributable chiefly to habitat degradation of the main rivers of the Paraíba do Sul basin. For instance, the Piabanha River was named Piabanha due to the presence of $B$. insignis in its waters. Although the deterioration of its water quality during recent years caused the extinction of piabanha, the river still holds the $B$. insignis common name (Figueiredo \& Rosas, 2003).

The present results showed that $B$. insignis populations are genetically different from each other, showing from the moderate to high level of genetic structure. Also, a clear bottleneck has been detected in the captive stock, possibly occurred during the broodstock formation. As a result, a 28$57 \%$ reduction in allelic richness was found when compared to wild population. Furthermore, PHC is genetically distinct from other wild populations and despite the low level of variability of this stock it is an important genetic resource of the species.

In the present situation, the recovery of $B$. insignis populations depends on two main implementation measures. The first measure is to conserve or even reverse habitat degradation of the rivers and riparian environments, where the species occurs so that natural recovery of wild populations can take place, as is the case of São João River (SJR). The second, is to promote stock enhancement into local areas where $B$. insignis populations no longer exist, as well as enhancement of populations in rivers where populations are extremely reduced. To implement such a measure, the genetic divergence still found among different populations of $B$. insignis must be taken into account establish the conservation strategies. This genetic variability can be maintained by keeping these populations in captivity under appropriate breeding management aimed at reducing the risks of genetic drift, inbreeding, and to minimizing the bottleneck effect present in the PHC (Duchesne \& Bernatchez, 2002).

Since the Brazilian legislation for aquatic environmental protection covers a set of measures that consider hatchery fish release and fish-passage facilities as methods for mitigating the impacts of river damming on fish, the knowledge of genetic differences among populations assessed in the present study may serve as the initial guidelines for establishing an adequate number of unrelated and noninbred founders for the future successful reintroduction programs of $B$. insignis.

\section{Acknowledgements}

We thank Andreia Mikami Sato, Danilo Caneppele, and the Paraibuna hatchery staff, and Guilherme Souza, of the Piabanha Foundation for their help with the fieldwork, and Messrs. Rodrigo Brandão Sakai and Edson Assis for the mapdrawing. We also thank the International Foundation for Science (\#A/3104-1) and the FAPESP (00/10.841-2) for granting funds to support this project. This work was developed as part of the full requirements for the Master's Thesis in Biotechnology at the UMC/FAEP.

\section{Literature Cited}

Abila, R., M. Barluenga, J. Engelken, A. Meyer \& W. Salzburger 2004. Population-structure and genetic diversity in a haplochromine fish cichlid of a satellite lake of Lake Victoria. Molecular Ecology, 13(9): 2589-2602.

Agostinho, A. A., L. C. Gomes, H. I. Suzuki \& H. F. Júlio Jr. 2003. Migratory fishes of the upper Paraná River Basin Brazil. Pp. 19-98. In: Carolsfeld, J., B. Harvey, C. Ross \& A. Baer (Eds.). Migratory Fishes of South America. Biology, Fisheries and Conservation Status. Victoria, BC: Co-published by World Fisheries Trust/World Bank/IDRC, 372p.

Allan, J. D. \& A. S. Flecker. 1993. Biodiversity conservation in running waters: Identifying the major factors that threaten destruction of riverine species and ecosystems. BioScience, 43(1): 32-43.

Andrade-Talmelli, E. F., E. T. Kavamoto, M. Y. Narahara \& N. Fenerich-Verani. 2002. Reprodução Induzida da Piabanha, Brycon insignis (Steindachner, 1876), mantida em Cativeiro. Revista Brasileira de Zootecnia, 31(2): 803-811.

Balloux, F. \& N. Lugon-Moulin. 2002. The estimation of population differentiation with microsatellite markers. Molecular Ecology, 11(2): 155-165.

Barroso, R. M. 2003. Isolamento de microssatélites em Pirapitinga do Sul (Brycon opalinus, Cuvier, 1819) e sua aplicação no estudo populacional da espécie na bacia do Paraíba do Sul. Unpublished Ph.D. Dissertation, Oswaldo Cruz Institute, Rio de Janeiro, 91p.

Barroso, R. M., A. W. S. Hilsdorf, H. L. M. Moreira, P. H. Cabello \& Y. W. Traub-Cseko. 2005. Genetic diversity of wild and cultured populations of Brycon opalinus (Cuvier, 1819) (Characiforme, Characidae, Bryconiae) using microsatellites. Aquaculture, 247(1-4): 51-65.

Barroso, R. M., A. W. S. Hilsdorf, H. L. M. Moreira, A. A. Mello, S. E. F. Guimarães, P. H. Cabello \& Y. M. Traub-Cseko. 2003. Identification and characterization of microsatellites loci in Brycon opalinus. Molecular Ecology Notes, 3: 297-298.

Beaumont, M. A. \& M. W. Bruford. 1999. Microsatellites in conservation genetics. Pp. 165-182. In: Goldstein, D. \& C. Schlötterer (Eds.). Microsatellites: Evolution and Applications. New York, Oxford University Press, 368p.

Bittencourt, M. M. \& C. Cox-Fernandes. 1990. Peixes migradores sustentam pesca comercial. Ciência Hoje, 11(64): 20-24.

Bizerril, C. R. S. F. 1999. Ictiofauna da Bacia do Rio Paraíba do Sul. Biodiversidade e Padrões Biogeográficos. Brazilian Archives of Biology and Technology, 42(2): 233-250.

Cornuet, J. M. \& G. Luikart. 1996. Description and power analysis of two tests for detecting recent population bottlenecks from allele frequency data. Genetics, 144(4): 2001-2014.

Di Rienzo, A., A. C. Peterson, J. C. Garza, A. M. Valdes, M. Slatkin $\&$ N. B. Freimer. 1994. Mutational processes of simple-sequence repeat loci in human populations Proceedings of the National Academy of Sciences, USA, 91(8): 3166-3170.

Duchesne, P. \& L. Bernatchez. 2002. An analytical investigation of the dynamics of inbreeding in multi-generation supportive breeding. Conservation Genetics, 3: 47-60.

Eizirik, E., J. H. Kim, M. Menotti-Raymond, P. G. Crawshaw, S. J. O’Brien \& W. E. Johnson. 2001. Phylogeography, population history and conservation genetics of jaguars (Panthera onca, Mammalia, Felidae). Molecular Ecology, 10(1): 65-79.

El Mousadik, A. \& R. J. Petit. 1996. Chloroplast DNA phylogeography of the argan tree of Morocco. Molecular Ecology, 5: 547-555. 
Excoffier, L., G. Laval \& S. Schneider. 2005. Arlequin ver. 3.1: an integrated software package for population genetics data analysis. Evolutionary Bioinformatics Online, 1: 47-50.

Excoffier, L., P. E. Smouse \& J. M. Quattro. 1992. Analysis of molecular variance inferred from metric distances among DNA haplotypes: application to human mitochondrial DNA restriction data. Genetics, 131(2): 479-491.

Felsenstein, J. 1985. Confidence limits on phylogenies: an approach using the bootstrap. Evolution, 39(4): 783-791.

Figueiredo, B. C. \& R. O. Rosas. 1997. Diagnóstico ambiental do Rio Piabanha, Petrópolis/RJ. Geo UERJ Revista do Departamento de Geografia, 1: 1040-1042. Available from http:// geografia.igeo.uerj.br/xsbgfa/cdrom/eixo3/3.3/152/152.htm.

Gomes, L. C., B. Baldisserotto \& J. A. Senhorini. 2000. Effect of stocking density on water quality, survival, and growth of larvae of the matrinxã, Brycon cephalus (Characidae), in ponds. Aquaculture, 183(1-2): 73-81.

Goodman, S. J. 1997. RST CALC: A collection of computer programs for calculating unbiased estimates of genetic differentiation and determining their significance for microsatellite data. Molecular Ecology, 6: 881-885.

Goudet, J. 2002. FSTAT, A Program to Estimate and Test Gene Diversities and Fixation Indices (version 2.9.3.2). Institute of Ecology, University of Lausanne, Switzerland. Available from http//www.unil.ch/izea/softwares/fstat.html.

Goudet, J. 2005. HIERFSTAT, a package for R to compute and test hierarchical F-statistics. Molecular Ecology Notes, 5(1): 184-186.

Goudet, J., M. Raymond, T. de Meeus \& F. Rousset. 1996. Testing differentiation in diploid populations. Genetics, 144: 1933-1940.

Guo, S. \& E. Thompson. 1992. Performing the exact test of HardyWeinberg proportion for multiple alleles. Biometrics, 48: 361-372.

Hilsdorf, A. W. S., F. C. Lima \& C. K. Matsumoto. 2008. Brycon insignis Steindachner (1877). Pp. 48-50. In: Machado, A. B. M., G. M. Drummond \& A. P. Paglia (Eds.). Livro vermelho da fauna brasileira ameaçada de extinção. Brasília, MMA.

Hilsdorf, A. W. S., C. Oliveira, F. C. T. Lima \& C. K. Matsumoto. 2008. Phylogenetic analysis of Brycon and Henochilus (Characiformes: Characidae: Bryconinae). Genetics and Molecular Biology, 31(Suppl. 1): 366-371.

Hilsdorf, A. W. S. \& M. Petrere Jr. 2002. Peixes na bacia do rio Paraíba do Sul: Aspectos de sua diversidade e conservação. Ciência Hoje, 30(180): 62-65.

Jarne, P. \& P. J. L. Lagoda. 1996. Microsatellites, from molecules to populations and back. Trends in Ecology \& Evolution, 11(10): 424-429.

Lande, R. 1988. Genetics and demography in biological conservation. Science, 241: 1455-1460.

Lima, F. C. T. 2003. Subfamily Bryconinae. Pp. 174-181. In: Reis, R. E., S. O. Kullander \& C. J. Ferraris (Eds.). Check list of the freshwater fishes of South and Central America. Porto Alegre, Edipucrs, 729p.

Lowe-McConnell, R. 1984. The Status of Studies on South American Freshwater Food Fishes. Pp. 139-156. In: Zaret, T. (Ed.). Evolutionary Ecology of Neotropical Freshwater Fishes. Netherlands, The Hague, Dr. W. Junk Publishers.

Machado, C. E. \& H. C. F. Abreu. 1952. Notas preliminares sobre a caça e a pesca no Estado de São Paulo - I. A Pesca no Vale do Paraíba. Boletim da Indústria Animal - SP, 13: 145-160.

Menezes, M. R., D. Noguchi, M. Nakajima \& N. Taniguchi. 2008. Microsatellite development and survey of genetic variation in skipjack tuna Katsuwonus pelamis. Journal of Fish Biology, 73(2): 463-473.
Miller, M. P. 1997. Tools for Population Genetic Analyses (TFPGA), 1.3. A windows program for the analyses of allozyme and molecular population genetic data. Utah State University. Available from http://bioweb.usu.edu/mpmbio/tfpga.asp.

Moritz, C. 1994. Defining “Evolutionary Significant Units” for conservation. Trends in Ecology and Evolution, 9: 373-375.

Nei, M. 1972. Genetic distance between populations. American Naturalist, 106: 283-292.

Nei, M. 1987. Molecular Evolutionary Genetics. New York, Columbia University Press, 512p.

O’Brien, S. J. 1994. A role of molecular genetics in biological conservation. Proceedings of the National Academy of Sciences, USA, 91: 5748-5755.

Oliveira, C., F. Foresti \& A. W. S. Hilsdorf. 2009. Genetics of neotropical fish: from chromosomes to populations. Fish Physiology and Biochemistry, 35(1): 81-100.

Reis, R. E., S. O. Kullander \& C. J. Ferraris (Eds.). 2003. Check list of the freshwater fishes of South and Central America. Porto Alegre, Edipucrs, 729p.

Rice, W. R. 1989. Analyzing table of statistical tests. Evolution, 43: 223-225.

Salgueiro, P., G. Carvalho, M. J. Collares-Pereira \& M. M. Coelho. 2003. Microsatellite analysis of genetic population structure of the endangered cyprinid Anaecypris hispanica in Portugal: implications for conservation. Biological Conservation, 109(1): 47-56.

Sanches, A. \& P. M. Galetti Jr. 2007. Genetic evidence of population structuring in the Neotropical freshwater fish Brycon hilarii (Valenciennes, 1850). Brazilian Journal of Biology, 67(Suppl. 4) 889-895.

Slatkin, M. 1995. A measure of population subdivision based on microsatellite allele frequencies. Genetics, 139: 457-462.

Taggart, J. B., R. A. Hynes, P. A. Prodohl \& A. Fergusson. 1992. A simplified protocol for routine total DNA isolation from salmonid fishes. Journal of Fish Biology, 40: 963-965.

Tautz, D. \& C. Schlotterer. 1994. Simple sequences. Current Opinion in Genetics and Development, 4: 832-837.

Van Oosterhout, C., W. F. Hutchinson, D. P. M. Wills \& P. Shipley. 2004. MICRO-CHECKER: software for identifying and correcting genotyping errors in microsatellite data. Molecular Ecology Notes, 4(3): 535-538.

Weir, B. S. \& C. C. Cockerham. 1984. Estimating F-statistics for the analysis of population structure. Evolution, 38(6): 1358-1370.

Wright, S. 1978. Evolution and the genetics of populations. vol. 4. Variability within and among natural populations. Chicago, University of Chicago Press, 580p.

Accepted July 20, 2009 Published September 30, 2009 